\title{
Identifying Housing Needs and Relation to Decrease in Cultivated Land: A Case Study of Bhetupara, Mohanpur, Rajshahi
}

\author{
Aftabun Nahar ${ }^{*}$, Rashiqul Islam, Saadman Reza Chowdhury, Abdul Wakil \\ Department of Urban \& Regional Planning, Rajshahi University of Engineering and Technology, Rajshahi, Bangladesh
}

Email address:

himu2010.13@gmail.com (A. Nahar)

${ }^{*}$ Corresponding author

\section{To cite this article:}

Aftabun Nahar, Rashiqul Islam, Saadman Reza Chowdhury, Abdul Wakil. Identifying Housing Needs and Relation to Decrease in Cultivated Land: A Case Study of Bhetupara, Mohanpur, Rajshahi. Landscape Architecture and Regional Planning. Vol. 3, No. 2, 2018, pp. 43-50. doi: $10.11648 /$ j.larp.20180302.14

Received: March 25, 2018; Accepted: June 7, 2018; Published: July 5, 2018

\begin{abstract}
In Bangladesh, most of the areas are rural. That is the reason for selecting a rural area to know about their problems and finding out a way to improve their condition. The study area is a village named Bhetupara which is located at Mohanpur upazila in Rajshahi district. The villagers are mainly engaged in agricultural activity. Housing is a basic need for mankind. The study is based on rural housing. The objective of the study is to know about their housing condition and needs and how it relates to decrease in cultivated land. Housing condition represents basically the condition of utility facilities in the village. The condition is shown by chart and data is collected from field survey. The study is based on both quantitative and qualitative data. For collection of data, Participatory Rural Appraisal (PRA) method and questionnaire are used. The used PRA tools are social map, transect and cause-effect diagram. The maps and diagram are prepared by focus group discussion with key informant. Social map and transect are used to know the existing condition and facilities and cause-effect diagram is used to know how housing affecting decrease in cultivated land and what will be the situation in future. This study reflects the dream of the people by including their recommendation. It will provide a base for development authority or planner to facilitate these rural people according to their expectation.
\end{abstract}

Keywords: Rural, Housing Needs, PRA Tools, Decrease in Cultivated Land

\section{Introduction}

Construction and distribution pattern of housing in a certain region develops according to the need of the inhabitants under a set of geographic control and changes with the evolution of the human needs at the different stages of the socio-economic and cultural development [11]. In Bangladesh about $80 \%$ of people live in rural settlements, and $86 \%$ of dwelling units are located in rural areas [2]. There has been very little public sector involvement in rural housing. There is virtually no land use plan for the rural area of this country. The present facilities in respect to housing and physical infrastructures are very inadequate in rural regions of Bangladesh. Traditionally, rural housing has been taken care by the rural villager's themselves. The government could not make any significant contribution in this respect. Housing varies in rural areas due to environmental and climatic diversity. The houses are built according to geographical features, ways of living and lifestyles of each area [3]. Housing condition depend on the economic and social state of the household. The categories of housing are basically affected by local environment and construction materials which are available locally in the context of the rural area [2].

With the increase of family members, households are expanding their homesteads in horizontal way that gradually decreasing agricultural lands in rural area. The traditional rural houses are well adapted to the local culture, environment and resources but none the less they also suffer from serious deficiencies [6]. Traditional rural dwellings are usually small, insanitary and suffer from the absence of many of the basic amenities of daily life [7].

For showing the present housing needs and finding some other rural housing aspect, a field survey is taken on a village 
of Mohanpur, Rajshahi. The village is in Maugacchi union and the name of the village is Bhetupara. There are around 171 household in this village. And number of population of this village is nearly 648 [8]. Among them 327 people are male and 321 people are female [8]. Survey was conducted to represent the condition of utility facilities and impacts on cultivated land. Because of the help of local expert and the participation of rural people, the survey run very smoothly. From this survey various type of data regarding rural housing was collected. As for example, data regarding type of structure, use of material for building house, problem regarding utility facilities, transportation problems and needs, their opinion etc. This data will help them who will interested for the further rural development plan in Bhetupara village.

\section{Methodology}

The principal objective of this study is to address the housing needs and problems according to utility facilities and impacts on land and infrastructure as stated in introduction. For notifying the actual scenario, household questionnaire survey and PRA method are conducted. The present study includes existing utility facilities of housing such as sanitation, drinking water facilities, drainage facilities, waste disposal facilities and electricity connection. For this study, literatures are reviewed for two times. First one is for choosing the topic and second one is to know about tools of PRA. The study takes overview some reports to analyze the objectives. These help to understand how can get the result. In this study both quantitative and qualitative approach has been used for the survey. With the help of key informant, social map and cause
$\&$ effects diagram are prepared. Transect walk is also prepared to particular condition of this village. Random and cluster sampling approach have been adopted to select respondents for household survey. Bhetupara has been divided into several groups of houses and one respondent has been selected randomly from the groups. Questionnaire was prepared so that housing condition related data can be collected. Generally, a single sample from a single household is taken. 50 household was taken by using random sampling method. Male and female both are participated in survey. The main categories of respondent are given below (table 1).

Table 1. Respondent Categories.

\begin{tabular}{ll}
\hline Categories & Percentage \\
\hline Farmer & 63.33 \\
Shopkeeper & 6.67 \\
Teacher & 10.00 \\
Day labour & 6.67 \\
House wife & 13.33 \\
\hline
\end{tabular}

Source: Field Survey, 2017.

\section{Study Area Profile}

The study area is located at Mohanpur upazila in Rajshahi. The name of the village is "Bhetu para" in Bakshimail union shown in figure 1. It is 35 kilometers away from main town of Rajshahi and 8 kilometers from Mohanpur. It is mainly an agricultural based village. There are about 171 households in Bhetu para [8]. This study considers only Bhetu para village as the study area. All the respondents are from Bhetu para \& village. The main crop of this area is betel leaf.

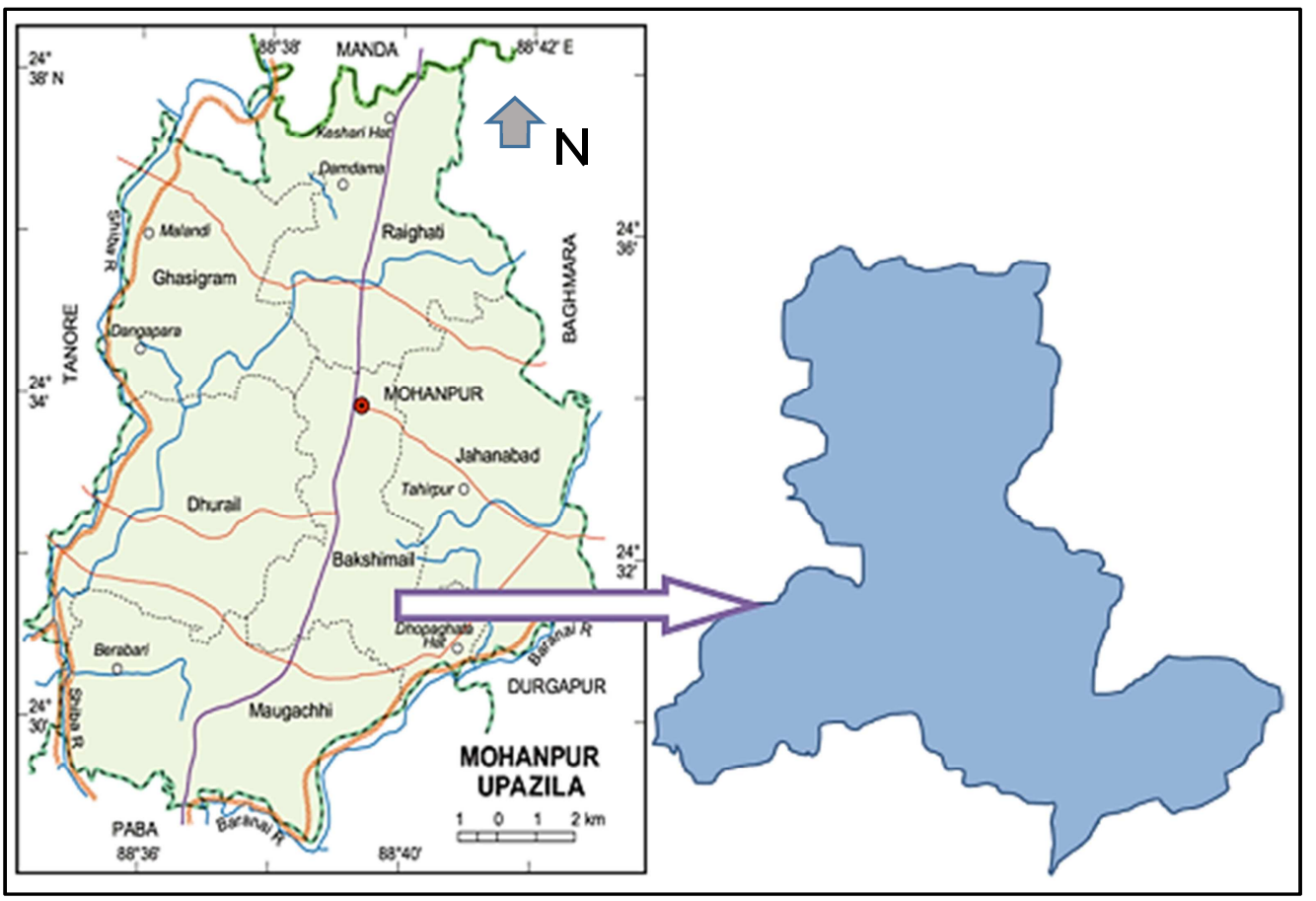

Source: LGED, 2017 [10].

Figure 1. Location of the Study Area 


\section{Literature Review}

Housing is a basic human need and as such provision of adequate housing for all citizens is almost universally recognized by government around the globe as one of their fundamental responsibilities. In the case of developing countries particularly, the gap between the demand and supply of adequate housing is continually increasing. This gap has been of alarming proportion in rural area. The reasons for such gaps are several, including the existing social structure rapid population growth, persisting poverty, and recurring natural hazards, but, also an unclear perception about the role of housing [5].

In their book, M. Hasan, M. S. Ullah and C. D. Gomes analyze the rural housing in Bangladesh. Though there is much similarity than difference in geographic condition, there are some variations in the housing characteristics. The houses that are commonly found in Bangladesh are described there. And also the characteristics of housing materials in rural area of Bangladesh is described. Mainly there are some types of material used on rural area [2]. They are:

a) Bamboo Walled Houses

b) Mud Walled Houses

c) Timber House

d) Timber and Brick Built Houses

e) Corrugated Iron (CI) / Tin Sheet Houses

f) Thatch / Straw Walled House

PRA is intended to enable local communities to conduct their own analysis and to plan and take action. PRA involves project staff learning together with villagers about the village. The aim of PRA is to help strengthen the capacity of villagers to plan, make decisions, and to take action towards improving their own situation. Participatory Rural Appraisal (PRA) is considered one of the popular and effective approaches to gather information in rural areas. In fact, it is a shift from extractive survey questionnaires to experience sharing by local people. PRA is based on village experiences where communities effectively manage their natural resources [12].

A transect walk takes the team on a mobile interview where team members walk through the community with "guides" from the village. The idea of a transect is to get the team out of the usual interview setting and to make use of people's powers of observation [12].

Social maps combine spatial analysis with ranking. In a social map, the various households in the community are noted on the map. Information about those families is then indicated using various symbols or markers. The team members will generally draw the map into their notebooks as it is being drawn by the villagers. In a PRA it is also good if there is some way to capture the results of the map so that the community can save it for their own future planning purpose [1].

A cause and effect diagram, often called a "fishbone" diagram, can help in brainstorming to identify possible causes of a problem and in sorting ideas into useful categories. The problem or effect is displayed at the head or mouth of the fish. Possible contributing causes are listed on the smaller "bones" under various cause categories. A fishbone diagram can be helpful in identifying possible causes for a problem that might not otherwise be considered by directing the team to look at the categories and think of alternative causes [4].

\section{Data Analysis}

\subsection{Electricity Facility}

Life comes to near standstill after sunset for the great majority of Bangladeshis living in the countryside. Only about $40 \%$ of rural households have access of grid electricity, and even these consumers suffer frequent and prolonged power cuts due to lack of supply [9].

But, electricity connection is very important for any kind of development. So, first concern is electricity facility. It is a very positive thing that Bhetupara village has $100 \%$ electricity connection. $100 \%$ electricity connection indicates that Bhetupara village has potentiality to improve social \& economic condition. Villagers get opportunity for improving their condition.

\subsection{Drinking Water Facilities}

Generally in rural areas, lack of pure drinking water is a great problem, and another problem is seasonal problem. But it is good to know that Bhetupara has no this types of problems (according to respondents).

\subsubsection{Drinking Water Source and Distance}

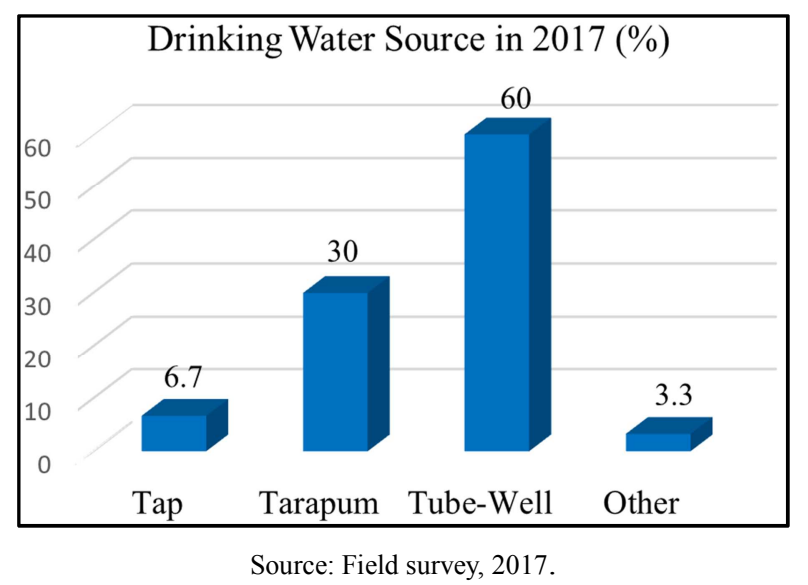

Figure 2. Drinking Water Source in 2017 (\%).

The main drinking water sources are tube well \& tarapam. Around $60 \%$ villagers use tube well and $30 \%$ villagers use tarapam shown in figure 2. Tap water facility is very low $(6.7 \%)$. Here, other source is irrigation water. There is no supply water services. Supply water is the need of villagers. Mainly they use tube well water for different purposes. Some of the use pond water for washing clothes, bathing etc. But for drinking water, almost everyone collects water from tube wells.

Water is used for not only drinking also for another 
purpose such as bathing, cooking, washing etc. This water is collected from pond, well, tube-well etc. Villagers collect their drinking water from tube-wells in different distance. They have to walk for a certain distance to collect drinking water. $73.3 \%$ respondent has drinking water source within 30 meter distance from house and $26.7 \%$ respondent has to go more than 30 meter for collecting water.

\subsubsection{Water Source Types and Shared Tube Well Household Number}

It is very important to know drinking water source types to identify the needs of drinking water source. There are two types of water sources such as shared (free) and owned. Here, shared (free) means peoples share their water sources but they have not to pay money for it.

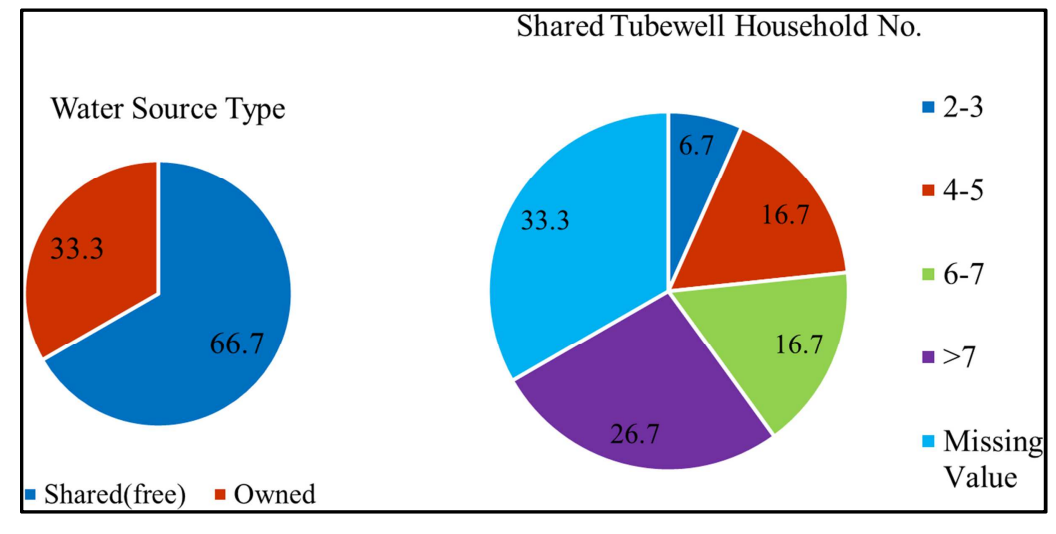

Source: Field survey, 2017

Figure 3. Water Source Type and Shared Household number.

And the percentages of shared (free) source is high approximately $66.7 \%$. On the other hand $33.3 \%$ villagers have their own water source. The owned sources percentage is nearly to the percentages of pucca houses $(26.7 \%)$. That means, all the pucca houses have owned water sources as shown in figure 8 .

Since the maximum water sources are shared, so it is a great concern to know about how many households share tube wells. According to figure 3, about $26.7 \%$ water source is shared by more than 7 households. $16.7 \%$ water source is shared by 6 to 7 households and also $16.7 \%$ water source is shared by 4 to 5 households and 2 to 3 households shared number is very low $(6.7 \%)$. Here, missing value percentage is high. Because, villagers have little knowledge about how many households share their sources.

\subsection{Sanitation}

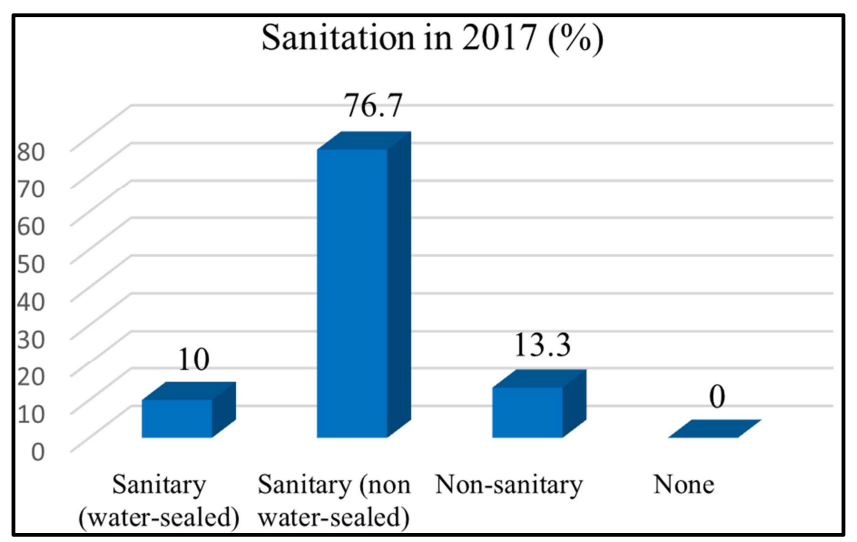

Source: Field survey, 2017

Figure 4. Sanitation in 2017 (\%).

Sanitation is one of the most important services for any kind of housing. If sanitation is not hygienic then many types of diseases can assail to human beings. The structural condition of toilet is katcha and pucca .

The supplies of sanitation facilities are good. Sanitary toilets are provided by Union Parishad. Figure 4 shows that total $86.7 \%$ villagers use sanitary toilets. Among them $76.7 \%$ are non-water sealed and $10 \%$ are water sealed. And $13.3 \%$ families use non sanitary toilet. There is no hanging toilets \& others.

\subsection{Access Road}

Transportation system is the heart of any area. In case of rural, all social \& economic prosperity depends on transportation system. In Bhetupara village the condition of access road is very poor. So, it is the main utility need of housing.

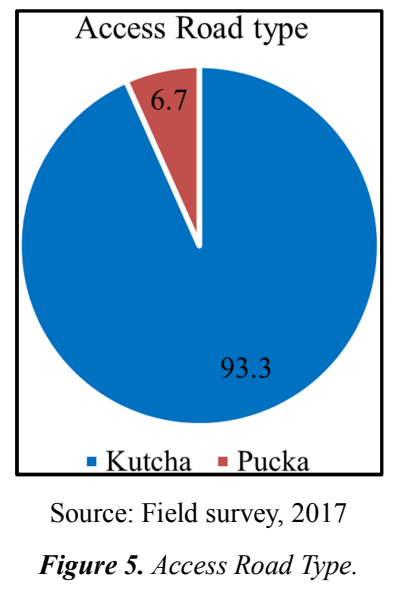

According to figure 5, 93.3\% access roads of this village are kutcha and $6.7 \%$ access roads are pucca. Because, inside 
the village all the roads are katcha and respondents who living beside the main road (Dhopaghata to Moupara road) have pucca type of road

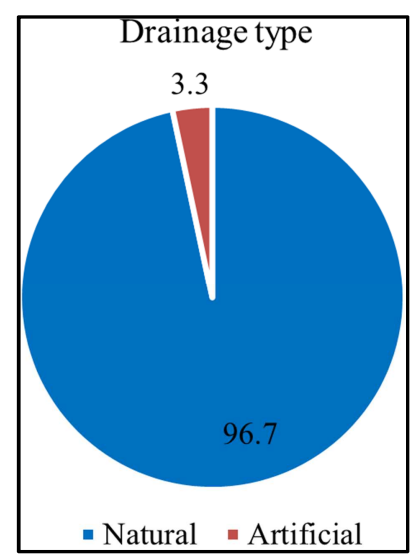

Source: Field survey, 2017

Figure 6. Drainage Type.

\subsection{Drainage Facilities}

According to respondents, $53.3 \%$ peoples have drainage facility and $46.7 \%$ peoples don't have drainage facility. Figure 6 shows that among $53.3 \%$ drainage facility, $96.7 \%$ is natural and $3.3 \%$ is artificial drainage.

It is good to know that there is no water logging problem according to respondents. It indicates that the topographic condition of Bhetupara village is good.

\subsection{Waste Disposal Facility and Dumping Places}

The garbage is an eyesore in any area and is a source of diseases. The accumulation of garbage's basically a consequence of lack of dumping sites in the area and the inability of City Corporation to collect the garbage from an appropriate place. So, it is great concern to identify the needs. $63.3 \%$ respondents said that they have waste disposal facility and $36.7 \%$ said that they don't have disposal facility (figure 7).

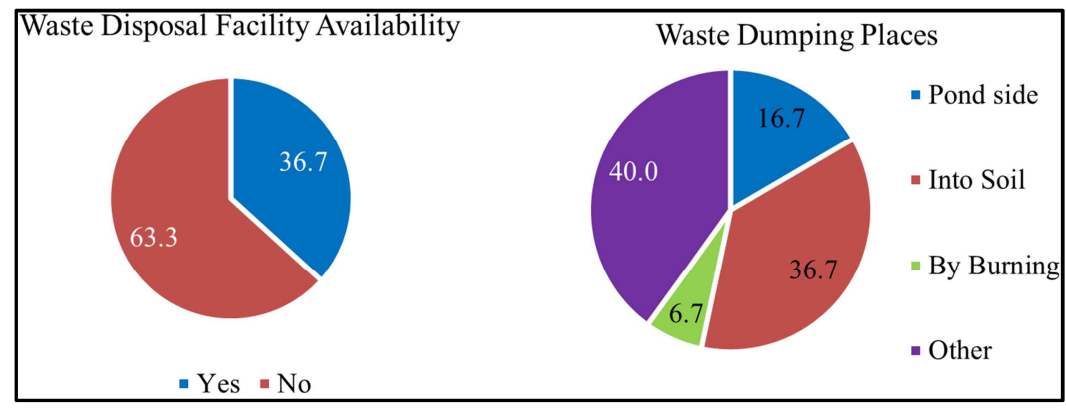

Source: Field survey, 2017

Figure 7. Waste Disposal Facilities and Dumping Places.

$36.7 \%$ respondents said that they dispose their waste into the soil. $16.7 \%$ wastages are dump on river side. And $6.7 \%$ said that, they burn their waste (shown in figure 7). Here, other means dumping by digging into the ground. Wastes which can be reused as a fertilizer, they dump the wastages by digging into ground.

\subsection{Housing Structure Type}

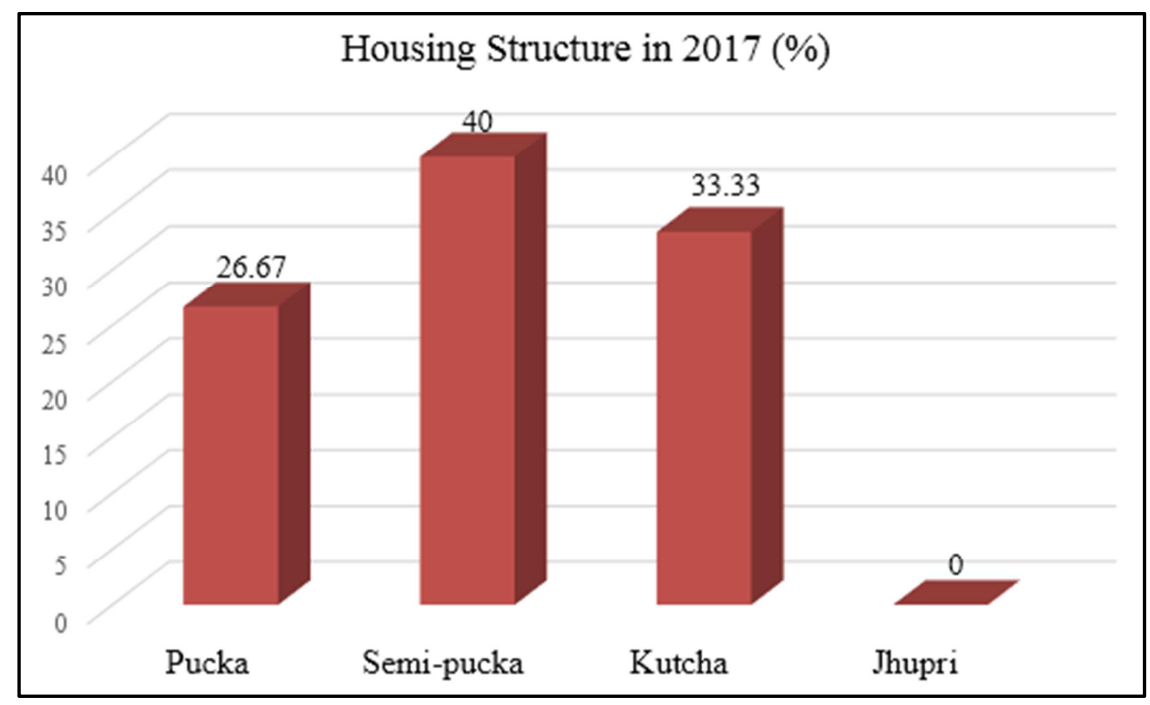

Source: Field survey, 2017

Figure 8. Housing Structure Type 2017(\%). 
Figure 8 shows the housing structure of Bhetupara. The percentages of semi-pucka houses $(40 \%)$ is more than pucka $(26.67 \%)$ and katcha houses $(33.33 \%)$. And there is no jhupri in this village.

\section{PRA Methods}

\subsection{Transects}

The survey team walks through the local mud road and take a section with local expert named Biplob from the centre of the Bhetupara village to its boundary. This Transect includes land use, vegetation, fisheries, crop, land fertility and structure type. Land uses mainly are house, pond, tree, road, paner boroj etc., in term of vegetation mainly are pui, lau, jhinga, paner boroj, mango etc., main fish are telepia, rui, katol, puti etc., land fertility is maximum fertile and others are none. There are three types of structure such as kutcha, semi-pucca and pucca houses. The transect walk map is shown in the following figure 9.

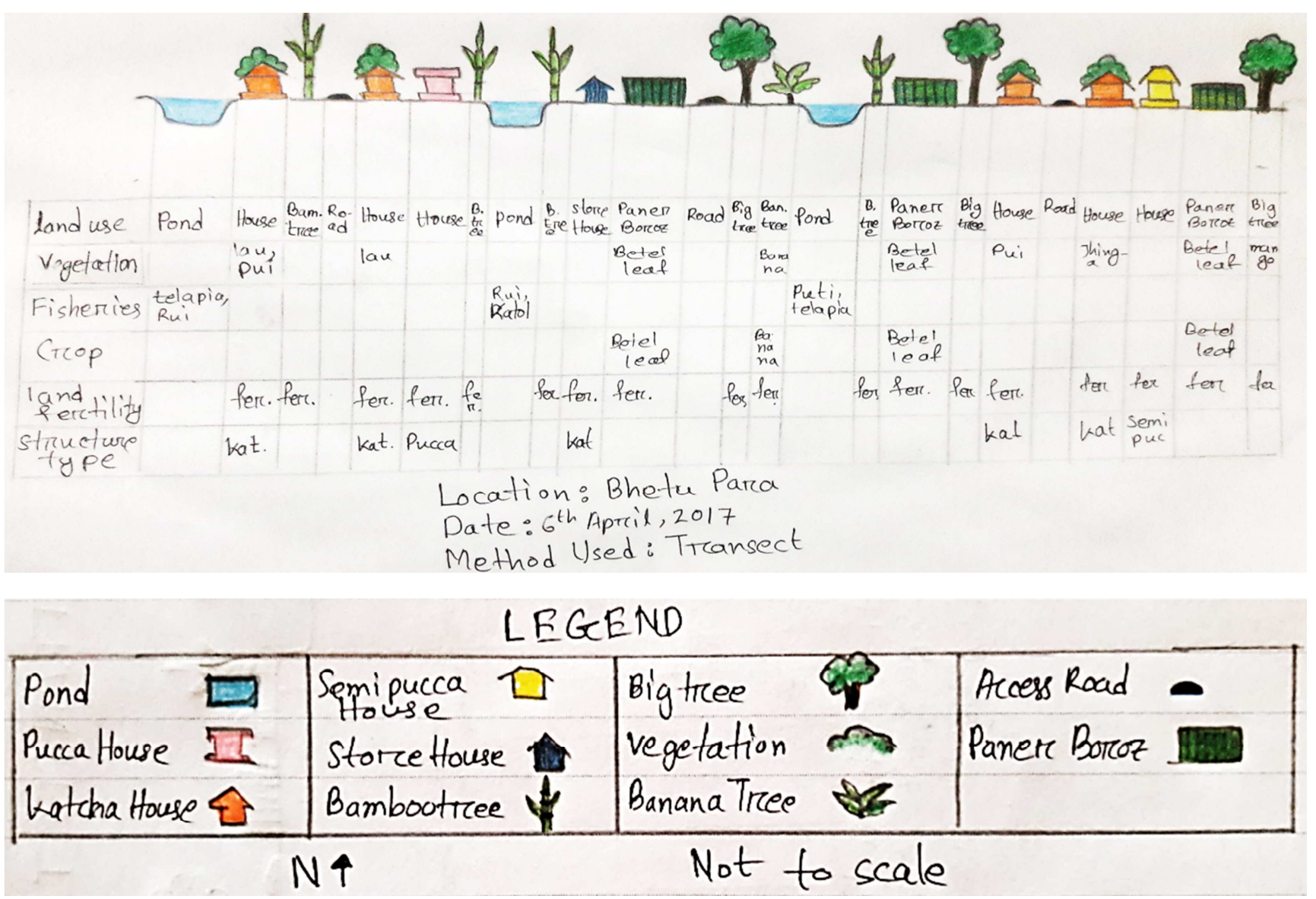

Source: Field survey, 2017

Figure 9. Transect Walk.

\subsection{Social Map}

Social map of Bhetupara shows housing structure, road and mosque. There are three type of housing structure kutcha, semipucca and pucca. Roads are two type kutcha and pucca. The map is given below in figure 10 . 


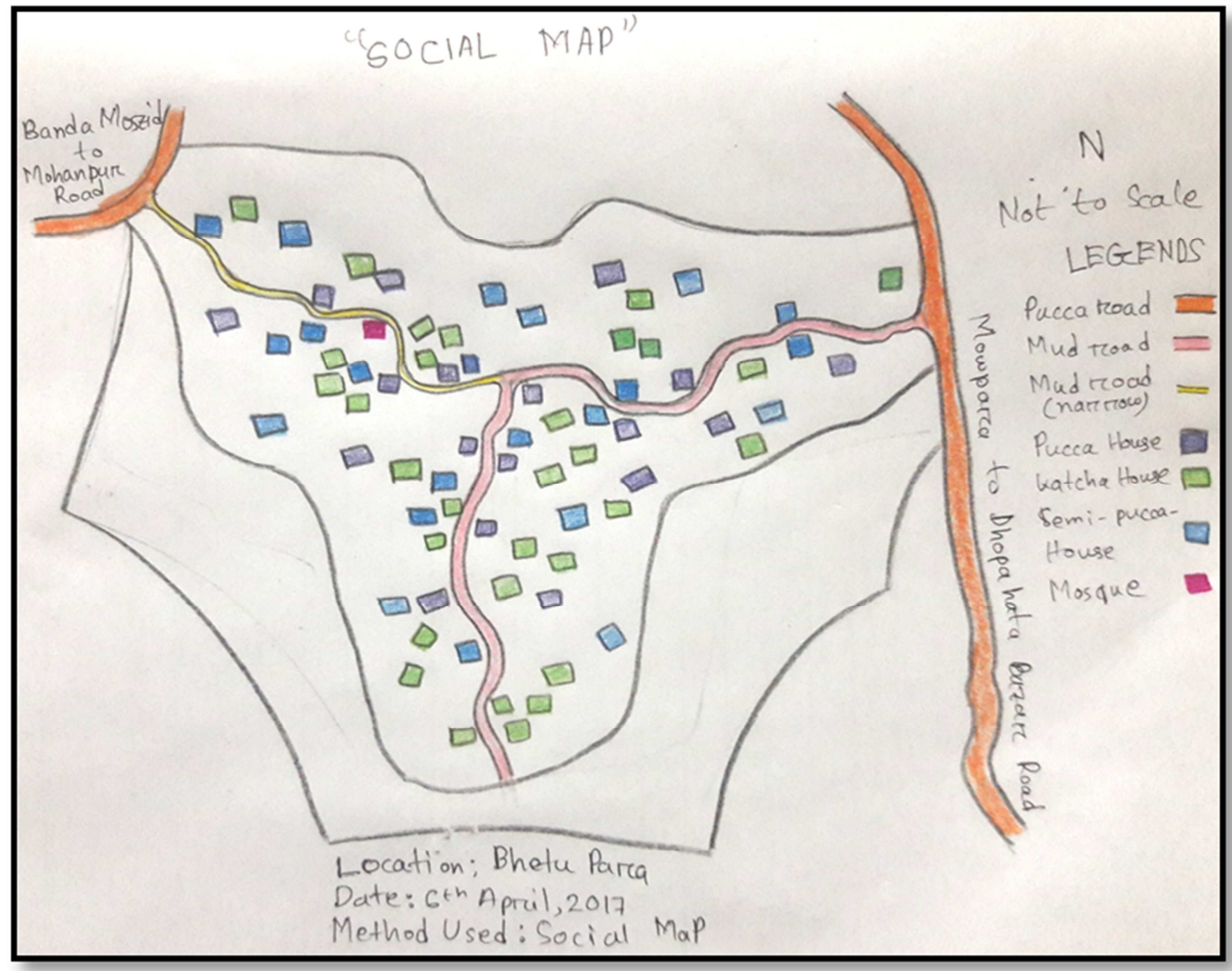

Source: Field survey, 2017

Figure 10. Social Map.

\subsection{Cause-Effect Diagram Showing the Relationship Between Housing Needs and Decrease in Cultivated Land}

The main issue of preparing cause-effect diagram is to show the relationship of household needs and decrease in cultivable land. The causes are family conflict, settlement growth, population growth and increase in number of houses and the effects are decreasing fertile land, decreasing production, increasing migration, environment degradation, increasing food price shown in figure 11. It can be said that there is an inverse relationship between housing needs and cultivated land. Increase in houses leads to decrease in cultivated land. It also affects the national economy and leads to unusual environmental effects.

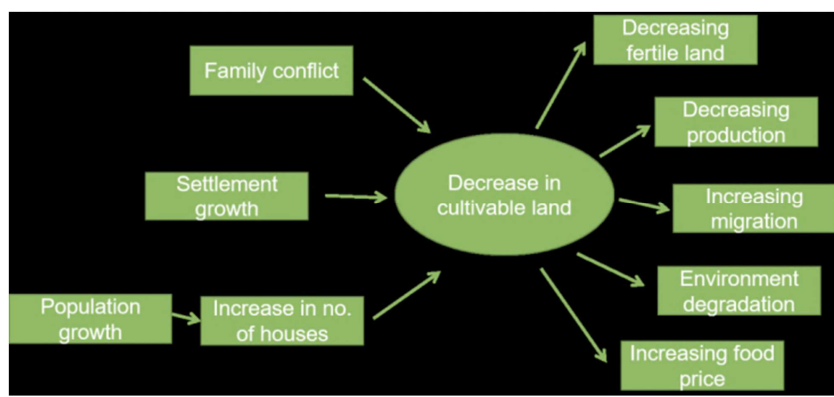

Source: Field survey, 2017

Figure 11. Cause-Effect Diagram.

\subsection{Respondent's Recommendation}

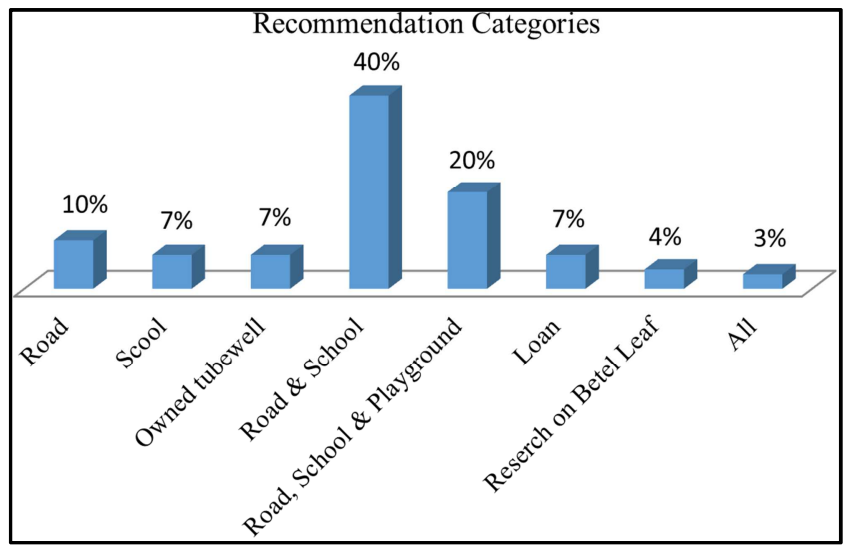

Source: Field survey, 2017

Figure 12. Respondents Recommendations.

Figure 12 represents respondent's recommendation categories. From the field survey, the data are collected through the questionnaire and after analysis that data, it is figured out that about $40 \%$ respondents recommend both development of pucca road and built of primary school. Other $20 \%$ respondents recommend development of pucca road, built of primary school and playground, $10 \%$ respondents recommend only development of school, 7\% respondents recommend only built of a primary school, 7\% respondents said that they need their owned tube-well, $7 \%$ 
respondents said that they need interest free or low interest loan from the government, $4 \%$ respondents said that it is needed to research on betel leaf and $3 \%$ respondents recommend all the categories. By this figure, it is known that pucca road and primary school are crying need of villagers.

\section{Conclusion}

Housing not only means a mere form of shelter but also it includes all those qualities of comfort, convenience and environmental amenities essential for social and emotional well-being of families. So, housing must be taken as first concern. The settlement pattern of Bhetupara village is semicompact. In Bhetupara, housing structure and facility are not so good. Because maximum peoples do not have money to develop there structure. Most of the structures are semipucca. Which is built by brick wall and tin shed. In terms of utility facilities the electricity connection, drinking water supply are good but the condition of access road is very bad because most of the portion of road is kutcha (mud road). In rainy season they face many difficulties in movement of people and goods. But, Bhetupara has potentialities to improve and there are many scope for development such as land, natural resources, man power, near from Rajshahi city centre etc. So, employment generation \& variation in occupation may help to develop their condition.

\section{References}

[1] Cavestro, L. (2003). P. R. A. - Participatory Rural Appraisal Concepts Methodologies and Techniques: UNIVERSITA' DEGLI STUDI DI PADOVA FACOLTA' DI AGRARIA.

[2] Hasan, M., Ullah, M. S., \& Gomes, C. D. (2000). Rural Housing in Bangladesh: An Inquiry into Housing Typology, Construction Technology and Indigenous Practices. The Proceedings of H \& H Conference (2000), Dhaka.
[3] Alam, A. A. F. M., Asad, A., \& Kabir, M. E. (2016). "Rural settlements dynamics and the prospects of densification strategy in rural Bangladesh". Journal of SpringerPlus. doi: 10.1186/s40064-016-1883-4.

[4] How to Use the Fishbone Tool for Root Cause Analysis. (2017). Retrieved May, 11, 2017, from https://www.google.com/url?sa=t\&source=web\&rct=j\&url=htt ps://www.cms.gov/medicare/provider-enrollment-andcertification/qapi/downloads/fishbonerevised.pdf\&ved $=0$ ahU KEwj0x9f19uXTAhVJK48KHSznCQEQFggdMAE\&usg=AF QjCNEp5j4FO-RaMUE-adQKs4fTQvvu8w.

[5] Islam, N. (1990). HOUSING IN BANGLADESH: AN OVERVIEW. Journal of Bangladesh Institute of Planners, 1, $37-45$.

[6] Uddin, N. (July, 2008) "A study on the traditional housing technology of Bangladesh," Indian Journal of Traditional Knowledge, 7(3), 494-500.

[7] Hafiz, R. (2000). "Financing Housing and Increasing Affordability of the Rural People in Bangladesh, Bangladesh," BUET, 2000.

[8] BBS (2011). Population And Housing Census, Rajshahi, Bangladesh Bureau Of Statistics (BBS), Statistical and Informatics Division (SID), Ministry of Planning Government of The People's Republic of Bangladesh, December 2013.

[9] Roy, K. K. (2014). Lighting Up Rural Communities in Bangladesh. Retrieved May, 8, 2017, from http://www.worldbank.org/en/news/feature/2014/01/15/lightin g-up-rural communities-in-bangladesh.

[10] Upazila Map, Local Government Engineering Department (LGED) (2017). Retrieved April, 16, 2017, from http://www.lged.gov.bd/.

[11] Rural House in Banglapedia (2017). Retrieved May, 17, 2017, from http://en.banglapedia.org/index.php?title=Rural_House.

[12] Kumar, S. (2002). Methods for Community Participation: A Complete Guide for Practitioners. New Delhi: Vistaar Publication. 